\title{
Використання сучасних мініінвазивних хірургічних технологій у лікуванні поєднаної патологіі анального каналу і прямої кишки
}

\author{
М. П. Захараш ${ }^{1}$, В. В. Балицький ${ }^{2,3}$, О. Г. Курик ${ }^{4}$ \\ ${ }^{1}$ Національний медичний університет імені О. О. Богомольця, м. Київ, \\ ${ }^{2}$ Вінницький національний медичний університет імені М. І. Пирогова, \\ ${ }^{3}$ Хмельницька обласна лікарня,
}

4Науково-практичний центр профілактичної та клінічної медицини Державного управління справами, м. Київ

\section{Application of modern miniinvasive surgical technologies in treatment of coexistant pathology in treatment of concomitant pathology of anal channel and recti}

\author{
M. P. Zakharash ${ }^{1}$, V. V. Balytskyy ${ }^{2,3}$, O. G. Kuryk ${ }^{4}$ \\ ${ }^{1}$ Bogomolets National Medical University, Kyiv, \\ ${ }^{2}$ Vinnytsya National Medical University named after M. I. Pyrogov, \\ ${ }^{3}$ Khmelnytskyi Regional Hospital, \\ ${ }^{4}$ Scientific-Practical Centre of Prophylactic and Clinical Medicine, Kyiv
}

\section{Реферат}

Мета. Покращити результати хірургічного лікування пацієнтів з поєднаною патологією анального каналу і прямої кишки за рахунок використання апарата радіохвильової хірургії «Surgitron».

Матеріали і методи. Проаналізовані результати лікування 236 пацієнтів з поєднаною патологією анального каналу і прямої кишки з використанням апарата радіохвильової хірургії «Surgitron».

Результати. Дослідженням встановлено, що використання апарата радіохвильової хірургії «Surgitron» 3меншує тривалість операції до $(15 \pm 5)$ хв, об'єм крововтрати - до (20 \pm 10$)$ мл, потребу в наркотичних аналгетиках - до (2 \pm 1$)$ мл, тривалість стаціонарного лікування - до (4 \pm 1$)$ день.

Висновки. Застосування апарата радіохвильової хірургії «Surgitron» скорочує тривалість операції, зменшує крововтрату під час операції, а також інтенсивність болю в післяопераційному періоді. Використання цієї мініінвазивної технології забезпечує незначну глибину некрозу тканин - $(0,2 \pm 0,1)$ мм і косметичність операції.

Ключові слова: поєднана патологія; анальний канал; пряма кишка; апарат радіохвильової хірургії «Surgitron».

Abstract

Objective. To improve results of surgical treatment in patients, suffering coexistent pathology of anal channel and rectum due to application of apparatus of radio-wave surgery «Surgitron».

Materials and methods. Results of treatment of 236 patients, suffering coexistent pathology of anal channel and rectum, using apparatus of radio-wave surgery «Surgitron».

Results. In the investigation there was established, that application of apparatus of radio-wave surgery «Surgitron» reduces the operation duration down to $(15 \pm 5) \mathrm{min}$, the blood loss volume - down to $(20 \pm 10) \mathrm{ml}$, the need in narcotic analgesic - down to $(2 \pm 1) \mathrm{ml}$, the stationary treatment stay - down to $(4 \pm 1)$ days.

Conclusion. Application of apparatus of radio-frequency surgery «Surgitron» shortens the operation duration, reduces the intraoperative blood loss, as well as the postoperative pain intensity. Application of this miniinvasive technology secures achievement of insignificant depth of the tissue necrosis - $(0,2 \pm 0,1) \mathrm{mm}$ and cosmetic efficacy of the procedure.

Keywords: coexistent pathology; anal channel; rectum; apparatus of radio-frequency surgery «Surgitron».

Останнім часом серед населення зростає поширеність проктологічних захворювань. Серед них поєднана патологія анального каналу і прямої кишки сягає 55-65\% $[1,2]$. Переважну більшість цих хворих складають пацієнти молодого працездатного віку [3].

Найбільш часто відзначається поєднання таких проктологічних захворювань: геморой і анальна тріщина - 21,6-60,7\%, геморой і хронічний парапроктит - 9,5$27,7 \%$, геморой і анальний поліп - 8,5-17,7\%, геморой, анальна тріщина і анальний поліп - 1,1-7,3\%, геморой, анальна тріщина і хронічний парапроктит - 1,7-7,5\% [46].

Велику групу складають пацієнти 3 так званим "циркулярним” розташуванням гемороїдальних вузлів III-IV стадії в поєднанні з іншими захворюваннями анального каналу і прямої кишки, коли досягнення радикалізму операції є ускладненим та, іноді, навіть неможливим через небезпеку розвитку рубцевих стриктур анального каналу $[7,8]$.

Для запобігання виникненню різних ускладнень після комбінованих оперативних втручань на анальному каналі та прямій кишці з приводу їх поєднаної патології необхідною умовою є застосування сучасних мініінвазивних хірургічних технологій.

Мета дослідження: покращити результати хірургічного лікування пацієнтів 3 поєднаною патологією анального каналу і прямої кишки шляхом використання апарата радіохвильової хірургії «Surgitron». 


\begin{tabular}{|c|c|c|c|}
\hline \multicolumn{4}{|c|}{$\begin{array}{l}\text { Характер виконаних оперативних втручань в залежності від варіанта поєднаної патології анального каналу } \\
\text { і прямої кишки }\end{array}$} \\
\hline \multirow{2}{*}{ Варіант поєднаної патології } & \multirow{2}{*}{ Характер операції } & \multicolumn{2}{|c|}{ Число хворих } \\
\hline & & абс. & $\%$ \\
\hline Комбінований геморой, хронічна анальна тріщина & Гемороїдектомія, висічення тріщини & 31 & 13 \\
\hline Хронічна анальна тріщина, анальний поліп & Висічення тріщини, поліпектомія & 40 & 17 \\
\hline Комбінований геморой, анальний поліп & Гемороїдектомія, поліпектомія & 23 & 9,7 \\
\hline Комбінований геморой, хронічний парапроктит & Гемороїдектомія, висічення фістули & 23 & 9,7 \\
\hline Зовнішній геморой, анальний поліп & Гемороїдектомія, поліпектомія & 18 & 7,2 \\
\hline Зовнішній геморой, хронічна анальна тріщина & Гемороїдектомія, висічення тріщини & 12 & 5 \\
\hline $\begin{array}{l}\text { Хронічна анальна тріщина, анальний поліп, } \\
\text { гіпертрофовані перианальні шкірні мітки }\end{array}$ & $\begin{array}{l}\text { Висічення тріщини, поліпектомія, } \\
\text { ексцизія міток }\end{array}$ & 11 & 4,6 \\
\hline $\begin{array}{l}\text { Комбінований геморой, } \\
\text { хронічна анальна тріщина, анальний поліп }\end{array}$ & $\begin{array}{l}\text { Гемороїдектомія, висічення } \\
\text { тріщини, поліпектомія }\end{array}$ & 10 & 4,2 \\
\hline $\begin{array}{l}\text { Зовнішній геморой, } \\
\text { хронічна анальна тріщина, анальний поліп }\end{array}$ & $\begin{array}{l}\text { Гемороїдектомія, висічення тріщини, } \\
\text { поліпектомія }\end{array}$ & 10 & 4,2 \\
\hline $\begin{array}{l}\text { Анальний поліп, } \\
\text { гіпертрофовані перианальні шкірні мітки }\end{array}$ & Поліпектомія, ексцизія міток & 10 & 4,2 \\
\hline Зовнішній геморой, хронічний парапроктит & Гемороїдектомія, висічення фістули & 8 & 3,4 \\
\hline Хронічний парапроктит, анальний поліп & Висічення фістули, поліпектомія & 8 & 3,4 \\
\hline $\begin{array}{l}\text { Хронічна передня, хронічна задня анальні тріщини, } \\
\text { анальний поліп }\end{array}$ & Висічення тріщин, поліпектомія & 6 & 2,6 \\
\hline $\begin{array}{l}\text { Хронічна анальна тріщина, } \\
\text { гіпертрофовані анальні сосочки }\end{array}$ & Висічення тріщини, папілектомія & 6 & 2,6 \\
\hline $\begin{array}{l}\text { Зовнішній геморой, } \\
\text { гіпертрофована перианальна шкірна мітка }\end{array}$ & Гемороїдектомія, ексцизія мітки & 4 & 1,6 \\
\hline $\begin{array}{l}\text { Хронічний внутрішній геморой III ст., } \\
\text { хронічна анальна тріщина }\end{array}$ & Гемороїдектомія, висічення тріщини & 4 & 1,7 \\
\hline Анальний поліп, перианальні кондиломи & Поліпектомія, ексцизія кондилом & 3 & 1,3 \\
\hline $\begin{array}{l}\text { Хронічна передня, хронічна задня анальні фістули, } \\
\text { комбінований геморой }\end{array}$ & Висічення фістул, гемороїдектомія & 3 & 1,3 \\
\hline Хронічний внутрішній геморой III ст., анальний поліп & Гемороїдектомія, поліпектомія & 3 & 1,3 \\
\hline $\begin{array}{l}\text { Хронічний внутрішній геморой III ст., } \\
\text { хронічний парапроктит }\end{array}$ & Гемороїдектомія, висічення фістули & 3 & 1,3 \\
\hline
\end{tabular}

\section{Матеріали і методи дослідження}

У період з вересня 2009 по серпень 2017 р. у відділенні проктології Хмельницької обласної лікарні оперовані 236 пацієнтів з поєднаною патологією анального каналу і прямої кишки з використанням апарата радіохвильової хірургії «Surgitron» (див. таблицю). Чоловіків було 142 (60,2\%), жінок - 94 (39,8\%) віком від 18 до 74 років. У 181 (77\%) пацієнта виявлено два захворювання, у $49(21 \%)-3$, у $6(2 \%)-4$.

Всім пацієнтам досліджуваної групи оперативні втручання виконані з використанням апарата радіохвильової хірургії «Surgitron F. F. Р. F. EMC» (Ellman International, Inc., USA).

В основі дії цього апарата лежить ефект перетворення електричного струму на радіохвилі з вихідною частотою 4,0 МГц, що впливає на тканину, яка розрізається, вона чинить опір проникненню радіохвиль, виділяючи тепло, під впливом якого клітини тканини на шляху радіохвиль розпадаються і випаровуються і тканина начебто «розходиться».

Контрольну групу склали 112 пацієнтів 3 поєднаною патологією анального каналу і прямої кишки, які були оперовані традиційно без використання апарата радіохвильової хірургії.

Всі оперативні втручання виконані під спинномозковою анестезією. Перед операцією всім пацієнтам про- ведено огляд перианальної і параректальних ділянок, пальцеве дослідження анального каналу і прямої кишки, ректороманоскопію, а також з метою дообстеження і виключення патології ободової кишки 28 (11,8\%) пацієнтам виконано іригоскопію, а 36 (15,2\%) - фіброколоноскопію.

Після оперативних втручань методом радіохвильової хірургії проводили морфологічне дослідження тканин 3 метою вивчення глибини їх некрозу, для порівняння використовували операційний матеріал після застосування звичайного металевого скальпеля. Операційний матеріал фіксували у 10\% розчині нейтрального формаліну. Далі використовували гістопроцесор карусельного типу STP-120, для заливки парафінових блоків станцію ЕС-350, для різки парафінових блоків - ротаційний мікротом серії НM - 340Е, для фарбування гістологічних препаратів - автомат Robot Stainer HMS740 (всі апарати фірми MICROM International GmbH, Germany). Препарати фарбували гематоксиліном і еозином. Використовували мікроскоп Axioskop 40 з фотокамерою Axio Cam MRc5 (Karl Zeiss).

\section{Результати}

У ході проведеного дослідження встановлено, що використання апарата «Surgitron» скорочувало тривалість операції в середньому до $(15 \pm 5)$ хв, в контрольній групі операція тривала в середньому (30 \pm 5$)$ хв. Об'єм кро- 
вовтрати в досліджуваній групі становив (20 \pm 10$)$ мл, у контрольній - $(40 \pm 10)$ мл. Больовий синдром у післяопераційному періоді був більш виражений у пацієнтів контрольної групи, вони потребували наркотичних засобів для знеболення (4 \pm 1$)$ мл, у досліджуваній групі (2 \pm 1$)$ мл. Період лікування у стаціонарі в досліджуваній групі був значно меншим - (4 \pm 1$)$ день, ніж у контрольній групі - (7 \pm 1$)$ день. В післяопераційному періоді у пацієнтів досліджуваної групи не виявлено ознак недостатності анального сфінктера і формування рубцевої стриктури анального каналу, у контрольній групі у 4 (3,6\%) пацієнтів сформувалась рубцева стриктура анального каналу, яка ліквідована консервативно (у 2) та оперативно (у 2).

Шляхом морфологічного дослідження встановлено, що використання радіохірургічного пристрою «Surgitron» забезпечувало збереження тканинної структури з утворенням по краю розрізу тонкого шару коагуляційного некрозу (шару карбонізаціі), середня глибина якого становила 0,165 мм (див. рисунок). Відмічали повнокрів'я судин, поодинокі дрібні крововиливи.

У разі використання металевого скальпеля по краях хірургічної рани були поширені крововиливи, що свідчило про значну травматизацію тканин, яка в подальшому уповільнювала загоєння рани та могла перешкоджати ii загоєнню первинним натягом, призводячи до виникнення рубцевих змін.

\section{Обговорення}

Застосування апарата радіохвильової хірургії «Surgitron» для лікування хворих 3 поєднаною патологією анального каналу і прямої кишки приводило до зменшення вдвічі тривалості оперативних втручань, яка становила в середньому $(15 \pm 5)$ хв, та об'єму крововтрати під час операції, яка становила в середньому (20 \pm 10$)$ мл.

Завдяки збереженню тканинної структури з утворенням тонкого шару карбонізації, середня глибина якого становила 0,165 мм, після застосування радіохірургічного пристрою "Surgitron" майже вдвічі зменшувалися больовий синдром і потреба в наркотичних засобах для знеболення у пацієнтів досліджуваної групи порівняно $з$ контрольною групою.

Механічна і термічна травма при використанні радіохвильового методу мінімальна, що сприяло швидшому загоєнню рани, ніж у контрольній групі, і формуванню ніжного післяопераційного рубця, що запобігало виникненню рубцевих стриктур анального каналу та недостатності анального сфінктера у пацієнтів досліджуваної групи.

\section{Висновки}

1. Використання апарата радіохвильової хірургіï «Surgitron» сприяе скороченню тривалості операції, вдвічі зменшує об'єм крововтрати під час операції, а також зменшує больовий синдром в післяопераційному періоді, скорочує терміни стаціонарного лікування пацієнтів, сприяючи їх швидкій медико-соціальній реабілітаціі.

2. Застосування цієї мініінвазивної технології запобігає виникненню недостатності анального сфінктера та

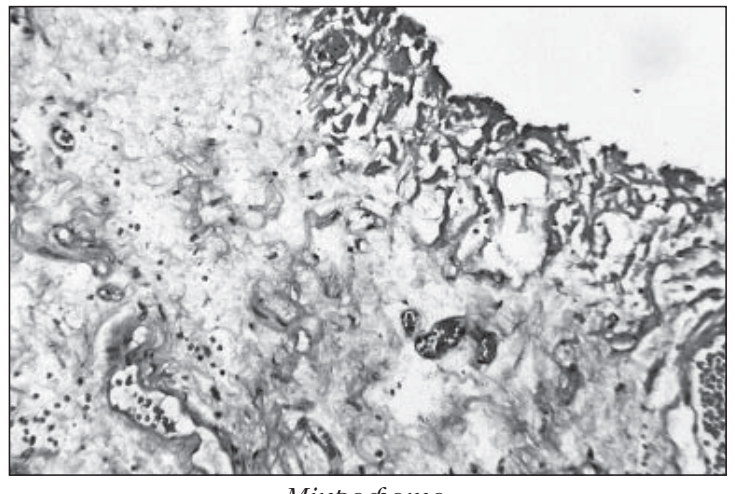

Мiкрофото.

Розтин тканин радіохвильовим методом: збереження тканинної структури з утворенням по краю розтину тонкого шару коагулячійного некрозу. Забарвлення гематоксиліном і еозином. Зб. ×100.

рубцевих стриктур анального каналу завдяки утворенню ніжного еластичного рубця як в анальному каналі, так і в параректальній ділянці, що забезпечує косметизм оперативного втручання і добрі функціональні результати після операції.

\section{References}

1. Foxx-Orenstein AE, Umar SB, Crowell MD. Common anorectal disorders. Gastroenterology and hepatology. 2014; 10(5): 294-301.

2. Klein IW. Common anal problems. The Medical Clin North Am. 2014 May;98(3):609-23. doi: 10.1016/j.mcna.2014.01.011. Epub 2014 Mar 21.

3. Tamm TI, Sedak VV, Datsenko AB, Bogun EA. Osobennosti lechenia osloznionnykch anal'nykch treshchin. In: materialy II siezda coloproctologov stran SNG, III siezda coloproctologov Ukrainy s uchastiem stran Tsentral'noi i Vostochnoi Evropy. Odessa; 2011: 519-20. [In Russian].

4. Shin IP, Pavlenko VV, Ptakchin AV, Gzogjan AA. Resul'taty odnomomentnykch operatsiy pri sochetannykch zabolevaniakch anorectal'noi oblasti. In: materialy II siezda coloproctologov stran SNG, III siezda coloproctologov Ukrainy s uchastiem stran Tsentral'noi i Vostochnoi Evropy. Odessa; 2011: 553-56. [In Russian].

5. Raiymbekov OR, Beishenaliev AS, Zholbolduiev ZM, Attokurov BK. Opyt lechenia anal'noi treshchiny v sochetanii s khronicheskim hemorroiem. Koloproctologia. 2015; 1(51) (prilozhenie): 42.[In Russian].

6. Borota AV, Hul'mamedov FI, Hul'mamedov VA, Polunin GE, Plakhotnikov IA, Shalamov VI. Khirurhicheskoe lechenie sochetannoi neopukholevoi patologii anal'nogo canala i priamoi kishki. Koloproctologia. 2016; 4(58): 22-5.[In Russian].

7. Popov IV, Karsakpaev KP. Primenenie shovnoi dezarterizatsii, mucopexii, lifting hemorroidal'nykh uzlov pri khirurhicheskom lechenii sochetannoi patilogii anal'nogo canala. Koloproctologia. 2015; 1(51) (prilozhenie): 35.[In Russian].

8. Mukhabbatov DK, Khaidarov SS, Karimov SA, Kasirov SN. Khirurhicheskoe lechenie hemorrhoia pri sochetanii s khronicheskoi anal'noi treshchinoi. Koloproctologia. 2015; 1(51) (prilozhenie): 36.[In Russian].

9. Mukhabbatov DK, Nosimov NK, Karimov SA, Khaidarov SS. Komplexnoe khirurhicheskoe lechenie hemorrhoia $\mathrm{v}$ sochetanii $\mathrm{s}$ transsphincternym svishchiom priamoi kishki. Koloproctologia. 2015; 1(51) (prilozhenie): 35-6.[In Russian].

10. Cherkasov DM, Cherkasov MF, Tatianchenko VK. Vybor sposoba lechenia sloznykh trans- i extrasphincternykh rectal'nykh svishchei. In: materialy III vserossiskoho siezda coloproctologov. Belgorod; 2011: 58. [In Russian]. 